\title{
RESEARCH
}

Open Access

\section{Global structural changes and their implication for territorial $\mathrm{CO}_{2}$ emissions}

\author{
K. Shironitta*
}

${ }^{*}$ Correspondence:

kayoko.s137@gmail.com

Graduate School

of Economics, Kyushu

University, Fukuoka-shi,

Fukuoka, Japan

\begin{abstract}
This paper proposes a comprehensive decomposition method to estimate how changes in domestic economic scale, industrial composition, domestic technology, export scale of intermediate products, export composition of intermediate products, export scale of final products, export composition of final products, import scale of intermediate products, import composition of intermediate products, import scale of final products, import composition of final products, and foreign technology affect the volumes of both territorial $\mathrm{CO}_{2}$ emissions (including emissions induced by producing exports) and extraterritorial $\mathrm{CO}_{2}$ emissions induced by imports. Specifically, the sources of the territorial $\mathrm{CO}_{2}$ emissions of each of 40 nations from 1995 to 2009 were examined using the Environmentally Extended World Input-Output Tables in 2009 prices. Based on the results, the patterns of structural change in the 40 nations can be classified into eight types and it can be seen that domestic industrial structure changes and import structure changes have different roles according to the group types. This study demonstrates the need for global warming countermeasures that consider the differences in the role that each country's structural changes play in $\mathrm{CO}_{2}$ emissions. We also found that the export composition effect was negligibly small in both the high-income and middle-income group of countries during 1995-2008 and it has not played an important role in climate change.
\end{abstract}

\section{Background}

Global territorial GHG emissions have increased continuously as nations have pursued economic growth. The average annual increase in GHG emissions for the decade 2000 through 2010 is $2.2 \%$ (IPCC 2014). According to Assessment Report 5 of the Intergovernmental Panel for Climate Change (IPCC), $\mathrm{CO}_{2}$ remains the major GHG, accounting for $76 \%$ of total GHG emissions. Changes in human population, per-capita gross domestic product (GDP), energy intensity of production, and $\mathrm{CO}_{2}$ emission intensities of energy production have affected fossil fuel-related $\mathrm{CO}_{2}$ emissions by $+87,+103,-35$, and $-15 \%$, respectively, over the 40-year period from 1970 to 2010 (IPCC 2014). These data imply that the positive effects of energy efficiency improvements on $\mathrm{CO}_{2}$ emissions have been canceled out by the increase in per-capita production and population.

While territorial and consumption-based $\mathrm{CO}_{2}$ emissions in Asia increased at relatively comparable rates from 1990 to 2010 (i.e., 175 and 197 \%, respectively), consumptionbased $\mathrm{CO}_{2}$ emissions in the OECD member nations increased at least three times as quickly as territorial $\mathrm{CO}_{2}$ emissions (i.e., production-based $\mathrm{CO}_{2}$ emissions) over the

(c) 2016 The Author(s). This article is distributed under the terms of the Creative Commons Attribution 4.0 International License (http://creativecommons.org/licenses/by/4.0/), which permits unrestricted use, distribution, and reproduction in any medium, provided you give appropriate credit to the original author(s) and the source, provide a link to the Creative Commons license, and indicate if changes were made. 
same period (IPCC 2014). The reason for this remarkable increase in consumptionbased $\mathrm{CO}_{2}$ emissions in OECD member nations has been the growing dependence on Asia for imports, which implies that the increase in $\mathrm{CO}_{2}$ emissions was attributable to international trade (Hertwich and Peters 2009; Davis et al. 2011; Peters et al. 2011).

Compared to territorial $\mathrm{CO}_{2}$ emissions, however, the accounting method for consumption-based $\mathrm{CO}_{2}$ emissions poses additional challenges, including the requirement for a deeper understanding of the global supply chain complexity associated with the final demand of nations. Conversely, accounting for the $\mathrm{CO}_{2}$ emissions directly generated to produce products (i.e., production-based $\mathrm{CO}_{2}$ emissions) is relatively straightforward. Therefore, it would be useful to be able to estimate the production-based $\mathrm{CO}_{2}$ emissions responsible for exports when evaluating how importing countries contribute directly to $\mathrm{CO}_{2}$ emissions induced by the domestic production activities of exporting countries. It is crucial to monitor the driving forces of the changes in not only production-based emissions but export-based emissions in making a climate change policy with a focus of territorial emissions.

In this study, we focus on recent changes in domestic economic structure in the world. The World Input-Output Database (WIOD) covering 40 developed and developing countries shows that from 1995 to 2009, the ratio of domestic output in the tertiary sectors of the 40 countries to the total output of those countries grew by $1.1 \%$, whereas that of domestic production in the primary and secondary sectors of those countries declined by $4.4 \%$ (Dietzenbacher et al. 2013). In addition, the dependence of the 40 countries on imports of primary and secondary products during the same period grew at rates of $2.1 \%$. In other words, domestic industrialization has rapidly weakened from 1995 to 2009 and this structural change has affected the environment.

A wide variety of indexes and structural decomposition techniques have been developed to analyze the effects of structural changes on energy consumption and the environment (Leontief and Ford 1972; Proops 1984; Rose and Chen 1991; Park 1992; Lin and Polenske 1995; Rose and Casler 1996; Casler and Rose 1998; Sun 1998; Wier 1998; Kagawa and Inamura 2001; Ang et al. 2003; Ang 2004; Levinson 2009; Wood and Lenzen 2009; Kagawa et al. 2012; Oshita 2012; Okamoto 2013). For example, methodological and empirical comparisons of index decomposition analyses (IDA) and structural decomposition analyses (SDA) were presented in Hoekstra and van den Bergh (2003). In a recent important IDA study, Voigt et al. (2013) used the WIOD to examine energy intensity trends and drivers in 40 major economies and estimated the effects of changes in the sectoral composition of the global economy as well as regional structural changes in energy intensities. However, they did not argue that domestic structural changes are strongly related to import structural changes. For climate change policy, it is crucial to examine the effects of both changes in industrial composition and import composition on greenhouse gas emissions (Hertwich and Peters 2009; Peters et al. 2011; Davis et al. 2011). $\mathrm{Xu}$ and Dietzenbacher (2014) examined driving forces of the growth of $\mathrm{CO}_{2}$ emissions from 1995 to 2007 by applying the WIOD to a multiplicative decomposition technique (Dietzenbacher et al. 2000) and revealed that the growth in net export emissions (i.e., emissions embodied in exports minus emissions embodied in imports) in developed countries was mainly due to changes in the trade structure of final and intermediate products. The abovementioned articles focused on consumption-based emissions 
and so did not include empirical decomposition results that took into account production-based emissions, which should also be discussed by climate policy makers.

This paper proposes an additive decomposition method of production-based emissions and empirically examines the extent to which changes in the global industrial structure as well as changes in import structure and export structure have contributed to changes in production-based $\mathrm{CO}_{2}$ emissions (i.e., territorial $\mathrm{CO}_{2}$ emissions). Specifically, the territorial $\mathrm{CO}_{2}$ emissions of each of the 40 aforementioned nations from 1995 to 2009 were estimated using the Environmentally Extended World Input-Output Tables at 2009 prices (Dietzenbacher et al. 2013; Timmer et al. 2015). The Shapley-SunDietzenbacher-Los additive decomposition method (Park 1992; Dietzenbacher and Los 1997, 1998; Sun 1998; Ang et al. 2003; Ang 2004; Nansai et al. 2007, 2009; Kagawa et al. 2012) was then applied to examine the sources of changes in the territorial $\mathrm{CO}_{2}$ emissions. Based on these results, we examine how these structural changes have contributed to changes in $\mathrm{CO}_{2}$ emissions. It should be noted that empirical results from the additive decomposition used in this study are not directly comparable to those from previous studies using multiplicative decomposition techniques (e.g., Voigt et al. 2013; Xu and Dietzenbacher 2014).

The remainder of this paper is organized as follows: Sect. 2 describes the study methodology, Sect. 3 presents the data, Sect. 4 gives results and discussion, and Sect. 5 concludes the paper.

\section{Methods}

In this study, we clarify how a widely used multiregional input-output database is useful for estimating the effects of changes in industrial composition and trade patterns on production-based emissions. We employ additive decomposition techniques to examine the effects of technology, industrial composition, and economic scale on production-based emissions (Park 1992; Sun 1998; Ang et al. 2003; Ang 2004). Furthermore, we develop a decomposition method for examining the effects of changes in the composition of both regional and sectoral imports on $\mathrm{CO}_{2}$ emissions.

The WIOD database from 1995 to 2009 (Dietzenbacher et al. 2013; Timmer et al. 2015) covers 35 industrial sectors and 40 countries (Tables 4, 5 in the Appendix). Using the time series multiregional input-output tables, total territorial emissions $Q_{d}^{t}(s)$ induced by manufacturing activities in country $s$ in year $t$ can be expressed as follows:

$$
\begin{aligned}
Q_{d}^{t}(s) & =\sum_{i=1}^{N} e_{i}^{t}(s) \theta_{i}^{t}(s) X_{d}^{t}(s) \\
& =\mathbf{e}^{t}(s) \boldsymbol{\theta}^{t}(s) X_{d}^{t}(s)
\end{aligned}
$$

where $\mathbf{e}^{t}(s)=\left\{e_{i}^{t}(s)\right\}, \boldsymbol{\theta}^{t}(s)=\left\{\theta_{i}^{t}(s)\right\}$, and $X_{d}^{t}(s)$ are the emission intensity row vector describing $\mathrm{CO}_{2}$ emissions per unit output in industrial sector $i$ in country $s$ in year $t$, the industrial composition column vector describing the fraction of output from industry sector $i$ of total production across all industries in country $s$ in year $t$, and total industrial output summed over all industrial sectors in country $s$ in year $t$, respectively. The subscript $d$ denotes "domestic." $N$ is the number of industrial sectors.

The annual change in $Q_{d}^{t}(s)$ from year $t$ to year $t+1$ is then 


$$
\Delta Q_{d}(s)=\mathbf{e}^{t+1}(s) \boldsymbol{\theta}^{t+1}(s) X_{d}^{t+1}(s)-\mathbf{e}^{t}(s) \boldsymbol{\theta}^{t}(s) X_{d}^{t}(s)
$$

which can be re-arranged as

$$
\begin{aligned}
\Delta Q_{d}(s)= & \Delta \mathbf{e}(s) \boldsymbol{\theta}^{t}(s) X_{d}^{t}(s)+\mathbf{e}^{t}(s) \Delta \boldsymbol{\theta}(s) X_{d}^{t}(s)+\mathbf{e}^{t}(s) \boldsymbol{\theta}^{t}(s) \Delta X_{d}(s) \\
& +\Delta \mathbf{e}(s) \Delta \boldsymbol{\theta}(s) X_{d}^{t}(s)+\mathbf{e}^{t}(s) \Delta \boldsymbol{\theta}(s) \Delta X_{d}(s)+\Delta \mathbf{e}(s) \boldsymbol{\theta}^{t}(s) \Delta X_{d}(s) \\
& +\Delta \mathbf{e}(s) \Delta \boldsymbol{\theta}(s) \Delta X_{d}(s)
\end{aligned}
$$

The first term on the right-hand side of Eq. (3) represents the effects of changes in $\mathrm{CO}_{2}$ emission intensities on the estimated $\mathrm{CO}_{2}$ emissions, and the second and third terms represent the influence of changes in industrial composition and in gross output on $\mathrm{CO}_{2}$ emissions, respectively; the remaining four terms are interaction terms. Using the Shapley-Sun-Dietzenbacher-Los decomposition to classify the seven terms (including the interaction terms among the technology effect, the industrial composition effect, and the economic scale effect), the following is obtained:

$$
\begin{aligned}
\Delta Q_{d}= & \underbrace{\Delta \boldsymbol{e}^{t} X_{d}^{t}+\frac{1}{2}\left(\Delta \mathbf{e} \Delta \boldsymbol{\theta} X_{d}^{t}+\Delta \mathbf{e} \boldsymbol{\theta}^{t} \Delta X_{d}\right)+\frac{1}{3} \Delta \mathbf{e} \Delta \boldsymbol{\theta} \Delta X_{d}}_{\text {Technology effect }} \\
& +\underbrace{\mathbf{e}^{t} \Delta \boldsymbol{\theta} X_{d}^{t}+\frac{1}{2}\left(\Delta \mathbf{e} \Delta \boldsymbol{\theta} X_{d}^{t}+\mathbf{e}^{t} \Delta \boldsymbol{\theta} \Delta X_{d}\right)+\frac{1}{3} \Delta \mathbf{e} \Delta \boldsymbol{\theta} \Delta X_{d}}_{\text {Industrial composition effect }} \\
& +\underbrace{\mathbf{e}^{t} \boldsymbol{\theta}^{t} \Delta X_{d}+\frac{1}{2}\left(\Delta \mathbf{e} \boldsymbol{\theta}^{t} \Delta X_{d}+\mathbf{e}^{t} \Delta \boldsymbol{\theta} \Delta X_{d}\right)+\frac{1}{3} \Delta \mathbf{e} \Delta \boldsymbol{\theta} \Delta X_{d}}_{\text {Economic scale effect }}
\end{aligned}
$$

For notational convenience, the symbol $s$ denoting country is omitted.

Equation (4) does not allow an examination of the sources of changes in extraterritorial emissions due to direct imports of intermediate products that are necessary for domestic production and direct imports of final products. Therefore, in this study, the emissions associated with the direct imports of intermediate products and final products are formulated as follows:

$$
\begin{aligned}
Q_{m}^{t}(s)= & \sum_{r=1, r \neq s}^{R} \sum_{i=1}^{N} e_{i}^{t}(r) \lambda_{i}^{t, r s}(s) I M_{z}^{t}(s)+\sum_{r=1, r \neq s}^{R} \sum_{i=1}^{N} e_{i}^{t}(r) \pi_{i}^{t, r s}(s) I M_{f}^{t}(s) \\
& =\sum_{r=1, r \neq s}^{R} \mathbf{e}^{t}(r) \lambda^{t, r}(s) I M_{z}^{t}(s)+\sum_{r=1, r \neq s}^{R} \mathbf{e}^{t}(r) \pi^{t, r}(s) I M_{f}^{t}(s)
\end{aligned}
$$

where $Q_{m}^{t}(s), \lambda^{t, r}(s)=\left\{\lambda_{i}^{t, r s}(s)\right\}, \pi^{t, r}(s)=\left\{\pi_{i}^{t, r s}(s)\right\}, I M_{z}^{t}(s)$, and $M_{f}^{t}(s)$ are the total territorial emissions caused by imports, the import composition column vectors of the ratios of imports by industrial sector $i$ into country $s$ to the total imports for intermediate products and final products to country $s$, the total amount of imports of intermediate 
products, and the total amount of imports of final products for country $s$, respectively. $\mathbf{e}^{t}(r)=\left\{e_{i}^{t}(r)\right\}$ is the emission intensity row vector for country $r$, and $R$ is the number of countries.

The extraterritorial emissions due to importation can be decomposed in the same way, i.e., into the effects of technology, domestic import structure, and domestic import scale in the importing country:

$$
\begin{aligned}
& \Delta Q_{m}=\underbrace{\Delta \mathbf{e} \lambda^{t} I M_{z}^{t}+\frac{1}{2}\left(\Delta \mathbf{e} \Delta \lambda I M_{z}^{t}+\Delta \mathbf{e} \lambda^{t} \Delta I M_{z}^{t}\right)+\frac{1}{3} \Delta \mathbf{e} \Delta \lambda \Delta I M_{z}}_{\text {Overseas technology effect for intermedaite products }} \\
& +\underbrace{\Delta \mathbf{e} \pi^{t} I M_{f}^{t}+\frac{1}{2}\left(\Delta \mathbf{e} \Delta \pi I M_{f}^{t}+\Delta \mathbf{e} \pi^{t} \Delta I M_{f}\right)+\frac{1}{3} \Delta \mathbf{e} \Delta \boldsymbol{\pi} \Delta I M_{f}}_{\text {Overseas technology effect for final products }} \\
& +\underbrace{\mathbf{e}^{t} \Delta \lambda I M_{z}^{t}+\frac{1}{2}\left(\Delta \mathbf{e} \Delta \lambda I M_{z}^{t}+\mathbf{e}^{t} \Delta \lambda \Delta I M_{z}\right)+\frac{1}{3} \Delta \mathbf{e} \Delta \lambda \Delta I M_{z}}_{\text {Import composition effect for intermedaite products }} \\
& +\underbrace{\mathbf{e}^{t} \Delta \lambda I M_{z}^{t}+\frac{1}{2}\left(\Delta \mathbf{e} \Delta \pi I M_{f}^{t}+\mathbf{e}^{t} \Delta \pi \Delta I M_{f}\right)+\frac{1}{3} \Delta \mathbf{e} \Delta \pi \Delta I M_{f}}_{\text {Import composition effect for final products }} \\
& +\underbrace{\mathbf{e}^{t} \lambda^{t} \Delta M_{z}+\frac{1}{2}\left(\Delta \mathbf{e} \lambda^{t} \Delta I M_{z}+\mathbf{e}^{t} \Delta \lambda \Delta I M_{z}\right)+\frac{1}{3} \Delta \mathbf{e} \Delta \lambda \Delta I M_{z}}_{\text {Import scale effect for intermedaite products }} \\
& +\underbrace{\mathbf{e}^{t} \pi^{t} \Delta I M_{f}+\frac{1}{2}\left(\Delta \mathbf{e} \pi^{t} \Delta I M_{f}+\mathbf{e}^{t} \Delta \pi \Delta I M_{f}\right)+\frac{1}{3} \Delta \mathbf{e} \Delta \pi \Delta I M_{f}}_{\text {Import scale effect for final products }}
\end{aligned}
$$

The emissions associated with the direct export of intermediate products and final products are formulated as follows:

$$
\begin{aligned}
Q_{x}^{t}(s) & =\sum_{r=1, r \neq s}^{R} \sum_{i=1}^{N} e_{i}^{t}(s) \varepsilon_{i}^{t, s r}(s) E X_{z}^{t}(s)+\sum_{r=1, r \neq s}^{R} \sum_{i=1}^{N} e_{i}^{t}(s) \delta_{i}^{t, s r}(s) E X_{f}^{t}(s) \\
& =\sum_{r=1, r \neq s}^{R} \mathbf{e}^{t}(s) \varepsilon^{t, r}(s) E X_{z}^{t}(s)+\sum_{r=1, r \neq s}^{R} \mathbf{e}^{t}(s) \delta^{t, r}(s) E X_{f}^{t}(s)
\end{aligned}
$$

where $Q_{x}^{t}(s), \varepsilon^{t, r}(s)=\left\{\varepsilon_{i}^{t, s r}(s)\right\}, \delta^{t, r}(s)=\left\{\delta_{i}^{t, s r}(s)\right\}, E X_{z}^{t}(s)$, and $E X_{f}^{t}(s)$ are the total territorial emissions caused by exports, the export composition column vectors of the ratios of exports by industrial sector $i$ from country $s$ to the total exports of intermediate products and final products to country $r$, the total amount of exports of intermediate products, and the total amount of imports of final products for country $r$, respectively. $\mathbf{e}^{t}(s)=\left\{e_{i}^{t}(s)\right\}$ is the emission intensity row vector for country $s$.

Territorial $\mathrm{CO}_{2}$ emissions due to exportation can be decomposed into the effects of technology, domestic export structure, and domestic export scale in the exporting country: 


$$
\begin{aligned}
& \Delta Q_{x}=\underbrace{\Delta \mathbf{e} \varepsilon^{t} E X_{z}^{t}+\frac{1}{2}\left(\Delta \mathbf{e} \Delta \boldsymbol{\varepsilon} E X_{z}^{t}+\Delta \mathbf{e} \varepsilon^{t} \Delta E X_{z}\right)+\frac{1}{3} \Delta \mathbf{e} \Delta \boldsymbol{\varepsilon} \Delta E X_{z}}_{\text {Domestic technology effect for intermedaite products }} \\
& +\underbrace{\Delta \mathbf{e} \delta^{t} E X_{f}^{t}+\frac{1}{2}\left(\Delta \mathbf{e} \Delta \delta E X_{f}^{t}+\Delta \mathbf{e} \delta^{t} \Delta E X_{f}\right)+\frac{1}{3} \Delta \mathbf{e} \Delta \delta \Delta E X_{f}}_{\text {Domestic technology effect for final products }} \\
& +\underbrace{\mathbf{e}^{t} \Delta \boldsymbol{\varepsilon} E X_{z}^{t}+\frac{1}{2}\left(\Delta \mathbf{e} \Delta \boldsymbol{\varepsilon} E X_{z}^{t}+\mathbf{e}^{t} \Delta \boldsymbol{\varepsilon} \Delta E X_{z}\right)+\frac{1}{3} \Delta \mathbf{e} \Delta \boldsymbol{\varepsilon} \Delta E X_{z}} \\
& \text { Export composition effect for intermedaite products } \\
& +\underbrace{\mathbf{e}^{t} \Delta \delta E X_{z}^{t}+\frac{1}{2}\left(\Delta \mathbf{e} \Delta \delta E X_{f}^{t}+\mathbf{e}^{t} \Delta \delta \Delta E X_{f}\right)+\frac{1}{3} \Delta \mathbf{e} \Delta \delta \Delta E X_{f}}_{\text {Export composition effect for final products }} \\
& +\underbrace{\mathbf{e}^{t} \boldsymbol{\varepsilon}^{t} \Delta E X_{z}+\frac{1}{2}\left(\Delta \mathbf{e} \varepsilon^{t} \Delta E X_{z}^{t}+\mathbf{e}^{t} \Delta \boldsymbol{\varepsilon} \Delta E X_{z}\right)+\frac{1}{3} \Delta \mathbf{e} \Delta \boldsymbol{\varepsilon} \Delta E X_{z}}_{\text {Export scale effect for intermedaite products }} \\
& +\underbrace{\mathbf{e}^{t} \delta^{t} \Delta E X_{f}+\frac{1}{2}\left(\Delta \mathbf{e} \delta^{t} \Delta E X_{f}^{t}+\mathbf{e}^{t} \Delta \delta \Delta E X_{f}\right)+\frac{1}{3} \Delta \mathbf{e} \Delta \delta \Delta E X_{f}}_{\text {Export scale effect for final products }}
\end{aligned}
$$

\section{Data}

In this study, the WIOD (Dietzenbacher et al. 2013; Timmer et al. 2015) and the Environmental Accounts, which are downloadable from the data website: http://www.wiod.org/ new_site/data.htm, are employed. These data cover 35 industrial sectors and 40 countries and region (Tables 4, 5 in the Appendix) and focus on the period of 1995-2011. For this study, the nominal World Input-Output Tables for 1995-2009 were converted into deflated World Input-Output Tables based on 2009 prices using the double deflation method (United Nations 1999). The deflators were obtained from the output prices of the nominal World Input-Output Tables and of the real World Input-Output Tables in previous year's prices.

The industrial composition column vector and total industrial output of 40 countries and region are calculable from the domestic outputs described in the deflated World Input-Output Tables, and the industrial $\mathrm{CO}_{2}$ emissions for 40 countries are obtainable from the Environmental Accounts (Dietzenbacher et al. 2013; Timmer et al. 2015). The emission intensity row vector can be easily obtained by dividing industrial $\mathrm{CO}_{2}$ emissions by industrial outputs. The data on intermediate inputs and final demand of goods and services are directly obtainable from the deflated World Input-Output Tables.

\section{Results and discussion}

In this section, the results of year-on-year changes in territorial $\mathrm{CO}_{2}$ emissions in 40 countries over the 15-year period from 1995 to 2009 are described using the decomposition method formulated in the previous section. Per-capita incomes published by the World Bank for the 40 countries (World Bank 2013) were used to classify the countries into three groups: high-income nations with per-inhabitant annual incomes of $\geq \$ 12,616$, middle-income nations with per-inhabitant annual incomes of $\geq \$ 4086$ and $<\$ 12,616$, and low-income nations with per-inhabitant annual incomes of $<\$ 4086$. For 
this study, 31 of the 40 countries were classified as high-income, seven were classified as middle-income, and two were classified as low-income (Tables 5 in the Appendix).

\subsection{Economic scale effect, industrial composition effect, and domestic technology effect} This study focused on four periods (1995-2000, 2000-2005, 2005-2008, and 20082009) and estimated the effects of changes in economic scale, industrial composition, and domestic technology during those periods using Eq. (4). Table 1 shows the decomposition results on "country average" in the three groups. It should be noted that the international financial crisis occurred between 2008 and 2009.

Table 1 Results of decomposing territorial $\mathrm{CO}_{2}$ emissions (Unit: $\mathrm{Mt} \mathrm{CO}_{2}$ )

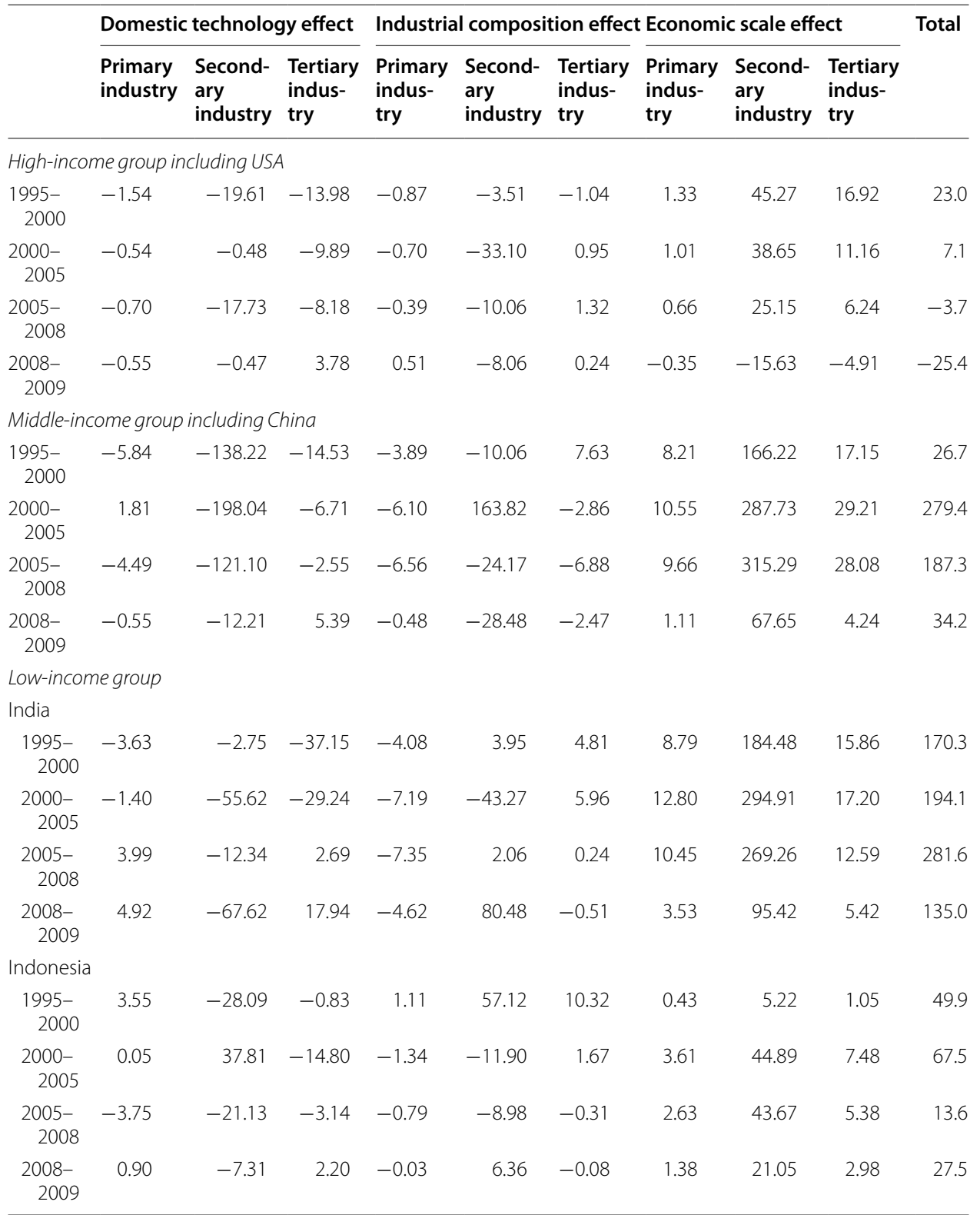


The economic scale effect reflects the influence of changes in the overall domestic industrial output on $\mathrm{CO}_{2}$ emissions. The cumulative economic scale effect in the highincome nations contributed to an increase in emissions of $146 \mathrm{Mt} \mathrm{CO}_{2}$ in the three industries from 1995 to 2008 (Table 1). On the other hand, territorial $\mathrm{CO}_{2}$ emissions decreased by $21 \mathrm{Mt} \mathrm{CO}_{2}$ in the three industries in response to the economic recession that followed the international financial crisis between 2008 and 2009 (see the economic scale effect in the high-income nation group during the 2008-2009 period in Table 1). Interestingly, during the 2008-2009 period, when the effect of the financial crisis reduced the average output of the high-income nations by $5.9 \%, \mathrm{CO}_{2}$ emissions in the high-income nations also decreased by $5.4 \%$. In other words, the economic damage resulting from the financial crisis was partially offset by social benefits from a reduction in $\mathrm{CO}_{2}$ emissions. Prior to 2005, the cumulative effect of output growth in the highincome nations amounted to approximately $50-60 \mathrm{Mt} \mathrm{CO}_{2}$ every 5 years.

Conversely, the cumulative economic scale effect in the middle-income nations, such as China and Turkey, was $872 \mathrm{Mt} \mathrm{CO}_{2}$, which is six times that of the high-income nations from 1995 to 2008 (see the economic scale effect in the middle-income nations of Table 1). The growth in the economic scale effect of the middle-income nations in each of the three periods was extremely high at $192 \mathrm{Mt} \mathrm{CO}_{2}$ in 1995-2000, $328 \mathrm{Mt} \mathrm{CO}_{2}$ in 2000-2005, and $353 \mathrm{Mt} \mathrm{CO}_{2}$ in 2005-2008 (Table 1). Indeed, the rapid economic growth of the middleincome nations is the source of much of the world's $\mathrm{CO}_{2}$ emissions increases. Examining the sectoral breakdown of industries as they relate to the mean cumulative economic scale effect in the middle-income nations, we find that primary industries contributed 28 $\mathrm{Mt} \mathrm{CO}_{2}$, secondary industries contributed $769 \mathrm{Mt} \mathrm{CO}_{2}$, and tertiary industries contributed $74 \mathrm{Mt} \mathrm{CO}_{2}$ of $\mathrm{CO}_{2}$ emissions from 1995 to 2008 (see Table 1; Table 4 in the Appendix for industry groups). The growth of secondary industries in the middle-income nations therefore brought about an abrupt increase in $\mathrm{CO}_{2}$ emissions. Importantly, compared to the high-income nations, the economic scale effect in the middle-income nations during the financial crisis was positive, and consequently, even in the financial crisis, $\mathrm{CO}_{2}$ emissions in the middle-income nations (especially in China) have increased faster than the decrease in $\mathrm{CO}_{2}$ emissions in the high-income nations.

The industrial composition effects illustrate how changes in domestic industrial composition influence $\mathrm{CO}_{2}$ emissions. The cumulative industrial composition effect per country in the high-income nations was $-47 \mathrm{Mt} \mathrm{CO}_{2}$, a reduction in $\mathrm{CO}_{2}$ emissions in the three industries from 1995 to 2008 (Table 1). Breaking down the composition of the industries and their $\mathrm{CO}_{2}$ emissions, we find that primary industries contributed $-2 \mathrm{Mt}$ $\mathrm{CO}_{2}$, secondary industries contributed $-47 \mathrm{Mt} \mathrm{CO}_{2}$, and tertiary industries contributed $1 \mathrm{Mt} \mathrm{CO}_{2}$ during the study period (Table 1). In addition, the industrial composition effect of secondary industries took on a large negative value because the emission intensities of secondary products are relatively high. On the other hand, the industrial composition effect of tertiary industries was close to neutral on $\mathrm{CO}_{2}$ emissions. Thus, it is clear that the changes in the industrial composition of the high-income nations, namely the shift away from manufacturing to services, have contributed to reducing the territorial $\mathrm{CO}_{2}$ emissions of that group.

The cumulative industrial composition effect of the middle-income nations was 111 Mt $\mathrm{CO}_{2}$ per country during the 1995-2008 period, indicating that the changes in the 
middle-income nations increased domestic $\mathrm{CO}_{2}$ emissions (see the third column of Table 1). Similarly, from the calculated breakdown by industry, primary industries contributed $-17 \mathrm{Mt} \mathrm{CO}_{2}$, secondary industries contributed $+130 \mathrm{Mt} \mathrm{CO}_{2}$, and tertiary industries contributed $-2 \mathrm{Mt} \mathrm{CO}_{2}$ (Table 1). In contrast to the high-income nations, the middle-income nations heavily industrialized, and the resulting increase in emissions $\left(+111 \mathrm{Mt} \mathrm{CO}_{2}\right)$ due to industrialization in the middle-income nations exceeded the reduction in emissions $\left(-47 \mathrm{Mt} \mathrm{CO}_{2}\right)$ due to deindustrialization of the high-income nations. Ultimately, changes in industrial activities in both income groups contributed to global warming.

Production technologies have played a crucial role in global warming (IPCC 2014). Therefore, we also examined the extent to which changes in emission intensities due to changes in domestic technologies influenced $\mathrm{CO}_{2}$ emissions. The cumulative domestic technology effect in the high-income nations in the three industries from 1995 to 2008 was $-73 \mathrm{Mt} \mathrm{CO}_{2}$ per country (Table 1); this decrease is considered to reflect efforts by the high-income nations to adopt environmentally benign production activities. The secondary and tertiary industries showed particularly high cumulative technology effects, at $-38 \mathrm{Mt} \mathrm{CO}_{2}$ and $-32 \mathrm{Mt} \mathrm{CO}_{2}$, respectively, per country from 1995 to 2008 (Table 1). During the same period, domestic technology effects in the middle-income nations (e.g., China and Turkey) accounted for $-490 \mathrm{Mt} \mathrm{CO}_{2}$ per country, which was approximately seven times the cumulative domestic technology effect of the high-income nations. Compared to the high-income nations, which are relatively more technologically advanced, the middle-income nations have more room for technological development; as they make further advances in the future, they will have considerable potential to reduce emissions.

\subsection{Export scale effect and export composition effect}

Territorial $\mathrm{CO}_{2}$ emissions are influenced by the manufacturing of export products, so this is an important factor for understanding the emissions of a country. Additional file 1: Table S1 shows the results of decomposition, using a structural decomposition analysis of the $\mathrm{CO}_{2}$ emissions associated with exports, as obtained from Eq. (8). From 1995 to 2008, the export scale effects for intermediate products and final products of the highincome group each show a downward trend. On the other hand, for the export scale effect of the middle-income group, a comparison of the results from 1995 to 2009 with the results from 2005 to 2008 reveals that the export scale effects of intermediate products and final products both rose sharply, increasing by factors of 3 and 2.5, respectively. From Table 1, a comparison of the economic scale effect of the middle-income group of countries between the five-year period from 1995 to 2000 and the three-year period from 2005 to 2008 shows that the economic scale effect grew by a factor of 1.8. In light of this finding, it is clear that in the middle-income group of countries, export products are a major driver of territorial $\mathrm{CO}_{2}$ emissions associated with manufacturing. Furthermore, the export composition effect is negligibly small (Table S1) in both the high-income and middle-income group of countries. Focusing on the manufacturing activities within countries, we can assume that as exports continue to decrease in the high-income group, the $\mathrm{CO}_{2}$ emissions associated with exports will keep falling. Thus, emission controls focused on domestic demand will be important in cutting $\mathrm{CO}_{2}$ emissions. At the same 
time, in developing economies such as those of the middle-income group of countries, it is necessary to implement emission control measures that are focused on the volumes of manufactured exports.

\subsection{Import scale effect, import composition effect, and foreign technology effect}

Concomitant with the shift of domestic economies away from manufacturing to services has come an increasing dependence on the importation of manufactured goods, which has increased the emissions associated with imports (in this study, this increase in imports was observed to have the effect of increasing the territorial $\mathrm{CO}_{2}$ emitted in the import-partner country during production of goods for export). The emissions induced by imports consist of the territorial emissions associated with the production of the intermediate and final imported products. According to the data in the WIOD (Dietzenbacher et al. 2013), the import interdependence among the high-income nations in the 1995-2009 period decreased to approximately $10 \%$, while the fraction of imports in the high-income nations from the middle- and low-income nations almost doubled. Thus, the import dependence on developing countries is increasing rapidly, and these changes in the import structures of developed nations have accelerated $\mathrm{CO}_{2}$ emissions in developing nations.

Table 2 shows how the extraterritorial emissions attributed to imports can be decomposed into the import scale effect, import composition effect, and the foreign technology effect estimated by Eq. (6). The import scale effects for intermediate and final products shown in Table 2 are the effects of changes in total domestic imports on emissions in the import-partner country. Imports by the high-income nations decreased markedly due to the international financial crisis, resulting in the import scale effect being negative from 2008 to 2009 (see Table 2). In the high-income group, the cumulative import scale effects associated with the production of intermediate and final products were $27 \mathrm{Mt}$ $\mathrm{CO}_{2}$ and $6 \mathrm{Mt} \mathrm{CO}_{2}$ per country, respectively, during the 1995-2008 period.

In the middle-income nations, the cumulative import scale effects associated with the production of imports of intermediate and final products were $53 \mathrm{Mt} \mathrm{CO}_{2}$ and $10 \mathrm{Mt}$ $\mathrm{CO}_{2}$, respectively, during the 1995-2008 period. The import scale effect in the middleincome nations was greater than that in the high-income nations; in particular, the effect due to imports of intermediate products was twice that in the high-income nations (see Table 2). The main reason for this was that during the shift away from manufacturing by the high-income nations, although the demand for imports of intermediate products from secondary industries decreased, the demand for the same secondary industry products increased in the middle-income nations due to increased industrialization capacity and foreign trade.

The import composition of the nations examined here (in other words, their patterns of international trade) and their domestic industrial composition are intertwined with how domestic products were replaced by imported products. For this reason, changes in the output composition of domestic industries have increased the import composition of emissions-intensive products, and it is possible to evaluate how the structural changes with regard to these domestic and imported products affect $\mathrm{CO}_{2}$ emissions. The third and sixth columns of Table 2 show the import composition effects for intermediate and final products. A comparison of industrial composition effects (Table 1) and import 
Table 2 Results of decomposing extraterritorial $\mathrm{CO}_{2}$ emissions $\left(\mathrm{Kt} \mathrm{CO}_{2}\right)$

\begin{tabular}{|c|c|c|c|c|c|c|c|}
\hline & \multicolumn{3}{|c|}{ Intermediate products } & \multicolumn{3}{|c|}{ Final products } & \multirow[t]{2}{*}{ Total } \\
\hline & $\begin{array}{l}\text { Foreign } \\
\text { technology } \\
\text { effect }\end{array}$ & $\begin{array}{l}\text { Import } \\
\text { composi- } \\
\text { tion effect }\end{array}$ & $\begin{array}{l}\text { Import } \\
\text { scale effect }\end{array}$ & $\begin{array}{l}\text { Foreign } \\
\text { technology } \\
\text { effect }\end{array}$ & $\begin{array}{l}\text { Import } \\
\text { composi- } \\
\text { tion effect }\end{array}$ & $\begin{array}{l}\text { Import } \\
\text { scale effect }\end{array}$ & \\
\hline \multicolumn{8}{|c|}{ High-income group including USA } \\
\hline $1995-2000$ & -4122 & 708 & 12,622 & -492 & 38 & 2127 & 10,882 \\
\hline $2000-2005$ & -3015 & 783 & 6920 & -856 & 283 & 2033 & 6148 \\
\hline $2005-2008$ & -2536 & -1602 & 7088 & -685 & -87 & 1441 & 3619 \\
\hline 2008-2009 & -1490 & -795 & -8989 & -813 & -68 & -322 & $-12,477$ \\
\hline \multicolumn{8}{|l|}{ USA } \\
\hline $\begin{array}{r}1995- \\
2000\end{array}$ & $-27,169$ & 21,424 & 118,882 & -359 & -2263 & 6600 & 117,116 \\
\hline $\begin{array}{r}2000- \\
2005\end{array}$ & $-19,536$ & -7165 & 42,902 & -2922 & -1220 & 2640 & 14,698 \\
\hline $\begin{array}{r}2005- \\
2008\end{array}$ & $-18,629$ & -438 & 14,978 & -2055 & -774 & 2565 & -4354 \\
\hline $\begin{array}{r}2008- \\
2009\end{array}$ & -5504 & $-25,666$ & $-56,293$ & -1754 & 553 & 254 & $-88,410$ \\
\hline \multicolumn{8}{|c|}{ Middle-income group including China } \\
\hline $1995-2000$ & -445 & -342 & 11,714 & -491 & -1723 & 4008 & 12,034 \\
\hline $2000-2005$ & -2715 & -1848 & 16,776 & -47 & -565 & 3712 & 15,425 \\
\hline $2005-2008$ & -1305 & -3191 & 24,823 & -1186 & -1292 & 2335 & 17,791 \\
\hline 2008-2009 & -2471 & 1474 & -7146 & -1211 & -347 & 317 & -8608 \\
\hline \multicolumn{8}{|l|}{ China } \\
\hline $\begin{array}{l}1995- \\
2000\end{array}$ & 978 & 204 & 35,284 & 1315 & -2278 & 3335 & 37,660 \\
\hline $\begin{array}{r}2000- \\
2005\end{array}$ & -9009 & $-11,775$ & 94,489 & 1824 & -656 & 3864 & 95,604 \\
\hline $\begin{array}{r}2005- \\
2008\end{array}$ & -5420 & $-20,892$ & 138,921 & -901 & -1821 & 855 & 99,488 \\
\hline $\begin{array}{r}2008- \\
2009\end{array}$ & -8881 & 15,244 & $-21,549$ & -752 & 609 & 443 & $-18,692$ \\
\hline \multicolumn{8}{|c|}{ Low-income group } \\
\hline \multicolumn{8}{|l|}{ India } \\
\hline $\begin{array}{l}1995- \\
2000\end{array}$ & -2634 & -3697 & 15,998 & -783 & -60 & 1778 & 10,602 \\
\hline $\begin{array}{r}2000- \\
2005\end{array}$ & 486 & 23,733 & 20,817 & 228 & 1103 & 1421 & 47,787 \\
\hline $\begin{array}{l}2005- \\
2008\end{array}$ & -1227 & -9402 & 14,751 & -282 & -536 & 1273 & 4578 \\
\hline $\begin{array}{r}2008- \\
2009\end{array}$ & $-12,201$ & -169 & -4587 & 1448 & -93 & -578 & $-16,179$ \\
\hline \multicolumn{8}{|l|}{ Indonesia } \\
\hline $\begin{array}{r}1995- \\
2000\end{array}$ & -1150 & 289 & 3169 & -706 & 885 & -398 & 9998 \\
\hline $\begin{array}{r}2000- \\
2005\end{array}$ & 54 & 1580 & 4298 & -517 & 854 & 217 & 7802 \\
\hline $\begin{array}{r}2005- \\
2008\end{array}$ & 91 & -1302 & 5162 & -476 & 2 & 533 & -3147 \\
\hline $\begin{array}{r}2008- \\
2009\end{array}$ & -1800 & -1419 & -1396 & -34 & -70 & -241 & -9571 \\
\hline
\end{tabular}


composition effects (Table 2) for each income group shows that in the 10 years between 1995 and 2005, changes in the industrial composition of the high-income nations helped to reduce $\mathrm{CO}_{2}$ emissions, but changes in import patterns as a result of factors such as import substitution caused $\mathrm{CO}_{2}$ emissions to increase. Interestingly, in the three years from 2005 to 2008, changes in the import patterns of intermediate products by the highincome nations mitigated global warming.

Figure 1 is a world map showing the net industrial composition effect (that is, the industrial composition effect plus the import composition effect) of 40 countries from 1995 to 2008. The figure shows to what degree a nation's industrial structure (also taking import structure into account) contributes to increasing or decreasing emissions. As shown, China and the USA have very large net industrial composition effects. While changes in its industrial structure enabled the USA to achieve an $895 \mathrm{Mt} \mathrm{CO}_{2}$ reduction in emissions, changes in the industrial structure of China resulted in a $720 \mathrm{Mt} \mathrm{CO}_{2}$ increase in emissions. As in Tian et al. (2014), for the study period (1995-2008), we found that the industrial composition change in the four heavy manufacturing sectors of Basic Metals and Fabricated Metal, Machinery, Electrical and Optical Equipment, and Transport Equipment in China led to a rapid increase in $\mathrm{CO}_{2}$ emissions amounting to $17 \%$ of the effect of the China's structural changes $\left(119 \mathrm{Mt} \mathrm{CO}_{2}\right)$. Compared to these two major countries, changes in the industrial structure of European nations have had almost no impact on $\mathrm{CO}_{2}$ emissions. These data show that these two major countries will have major roles regarding $\mathrm{CO}_{2}$ emissions forward into the future.

\subsection{Discussion}

Since the import composition effect of intermediate products and final products in Table 2 can be estimated from the third and fourth terms, respectively, on the right-hand side of Eq. (6), larger intermediate and final product imports of a country imply a greater import composition effect. To grasp the impact that pure import pattern changes have on $\mathrm{CO}_{2}$ emissions, the 'normalized' import composition effect was estimated by dividing the import composition effect of intermediate products and that of final products by their respective import values. Similarly, the larger a country's domestic output value is,

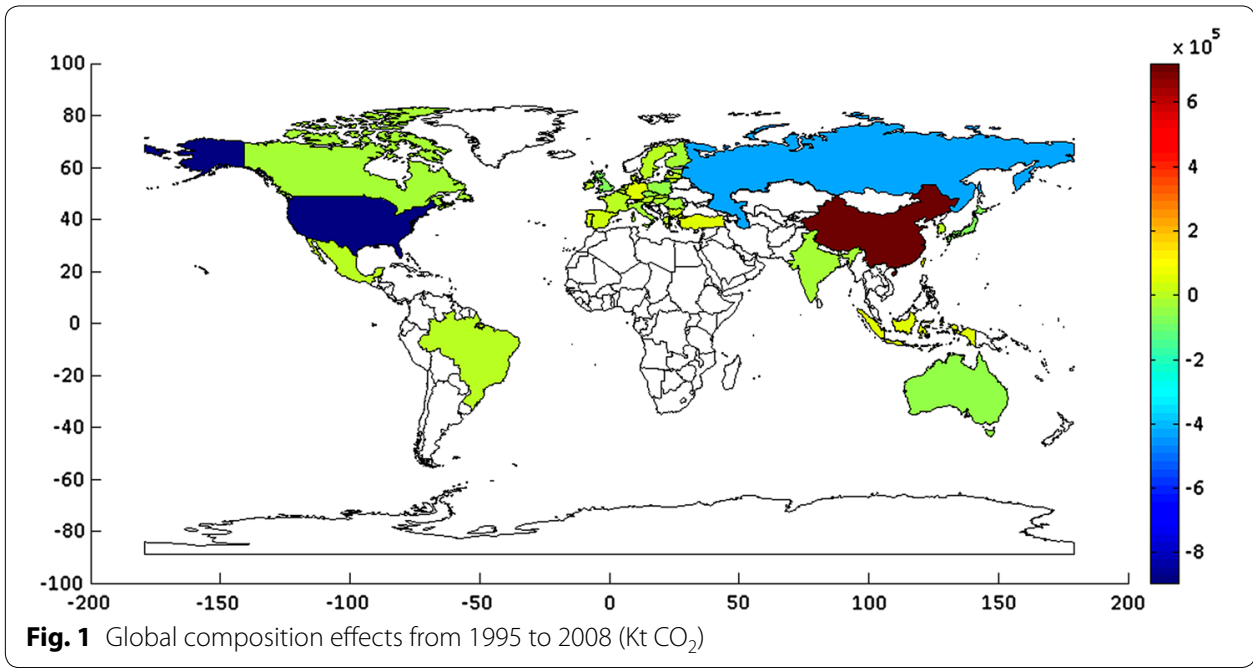


the greater its industrial composition effect will be; thus, a "normalized" industrial composition effect was estimated by dividing the industrial composition effect by the domestic output. By comparing the estimated normalized import composition effect and the normalized industrial composition effect for each country, it is possible to analyze the role that each country's pure structural changes play in global warming.

Table 3 shows the normalized import composition effect and normalized industrial composition effect for intermediate and final products in the 40 countries examined in this study. Based on the estimation results, the patterns of structural change in the 40 nations can be classified into eight types. The largest type group is Type II, which comprises nations for which the normalized industrial composition effect and normalized import composition effect for intermediate products are both negative, but normalized import composition effect for final products is positive. Type II countries, which include Japan, the UK, and Mexico, have reduced their emissions through structural changes (e.g., transitioning to a service economy), but have increased their emissions indirectly by increasing their import composition of emissions-intensive products for final products. The net composition effects (i.e., the sum of the normalized import composition effect for intermediate products, the normalized import composition effect for final products, and the normalized industrial composition effect) for most of countries of Type II are negative, which implies that their structural changes are environmentally good in the sense that they reduced emissions. However, the normalized import composition effects of final products for Japan, Luxembourg, and Mexico are relatively large compared to other countries classified as Type II, which resulted in positive net composition effects. This was especially high for Japan, which had the largest normalized import composition effect of final products among the high-income nations, and its structural changes, including its import structure changes, have contributed to increasing its $\mathrm{CO}_{2}$ emissions.

Interestingly, the net composition effect is very high (2.805; the total shown in Table 3 ) in Bulgaria (Type V), which was industrializing more rapidly than other countries between 1995 and 2008. Despite significant structural changes in Bulgaria, the composition effects of both intermediate product imports and final product imports were negative and these import activities contributed greatly to mitigate its responsibility for global warming. At 2.219, Indonesia (Type VIII) had the second highest net composition effect, but that is still markedly different from Bulgaria. Domestic structural changes in Indonesia have also caused emissions to increase, as in Bulgaria, but in Indonesia changes in import patterns have also contributed to global warming. Indonesia should therefore try to mitigate its contribution to global warming by encouraging the importation of substitutes for products that cause significant emissions. As for Bulgaria, it underwent its emissions-intensive industrial structural change relatively early compared to other countries and therefore should adopt policies aimed at reducing emissions from emissions-intensive industries. Thus, the impacts that structural changes have on $\mathrm{CO}_{2}$ emissions vary and are independent of a nation's level of development.

Recently implemented climate policies are conducted under a framework based on each country's level of economic development (e.g., per-capita income) and regional groupings, but the relationship between changes in industrial structure and global warming has been ignored. From Table 3, it can be found that domestic industrial structure changes and import structure changes have different roles according to group type. 
Table 3 Effects of industrial and import composition changes on $\mathrm{CO}_{2}$ emissions

\begin{tabular}{|c|c|c|c|c|c|c|}
\hline Country & $\begin{array}{l}\text { Income } \\
\text { group }\end{array}$ & $\begin{array}{l}\text { Normalized } \\
\text { import com- } \\
\text { position effect } \\
\text { of immediate } \\
\text { products }\end{array}$ & $\begin{array}{l}\text { Normal- } \\
\text { ized import } \\
\text { composition } \\
\text { effect of final } \\
\text { products }\end{array}$ & $\begin{array}{l}\text { Normalized } \\
\text { industrial } \\
\text { composition } \\
\text { effect }\end{array}$ & Total & $\begin{array}{l}\text { Type } \\
\text { for structural } \\
\text { changes }\end{array}$ \\
\hline EST & High & -0.079 & -0.075 & -0.577 & -0.731 & Type I \\
\hline FIN & High & -0.125 & -0.020 & -0.045 & -0.189 & \\
\hline ITA & High & -0.119 & -2.319 & -0.009 & -2.446 & \\
\hline SVK & High & -0.181 & -0.017 & -0.037 & -0.234 & \\
\hline CZE & High & -0.097 & 0.020 & -0.158 & -0.236 & Type II \\
\hline GBR & High & -0.076 & 0.076 & -0.059 & -0.058 & \\
\hline HUN & Middle & -0.173 & 0.065 & -0.130 & -0.238 & \\
\hline JPA & High & -0.474 & 0.955 & -0.098 & 0.383 & \\
\hline LUX & High & -0.078 & 0.202 & -0.016 & 0.108 & \\
\hline LVA & High & -0.145 & 0.100 & -0.030 & -0.074 & \\
\hline MEX & Middle & -0.002 & 0.102 & -0.010 & 0.090 & \\
\hline POL & High & -0.072 & 0.016 & -0.102 & -0.158 & \\
\hline ROM & High & -0.087 & 0.004 & -0.209 & -0.292 & \\
\hline RUS & High & -0.145 & 0.001 & -0.411 & -0.554 & \\
\hline BEL & Middle & 0.399 & -0.155 & -0.039 & 0.206 & Type III \\
\hline BRA & Middle & 0.028 & -0.114 & -0.007 & -0.094 & \\
\hline CAN & High & 0.103 & -0.091 & -0.022 & -0.010 & \\
\hline $\mathrm{KOR}$ & High & 0.040 & -0.712 & -0.006 & -0.678 & \\
\hline SVN & High & 0.143 & -0.051 & -0.038 & 0.054 & \\
\hline SWE & High & 0.048 & -0.007 & -0.019 & 0.022 & \\
\hline USA & High & 0.034 & -0.108 & -0.120 & -0.194 & \\
\hline AUS & High & 0.033 & 0.047 & -0.091 & -0.011 & Type IV \\
\hline IND & Low & 0.083 & 0.016 & -0.033 & 0.066 & \\
\hline LTU & High & 0.039 & 0.603 & -0.066 & 0.577 & \\
\hline NLD & High & 0.099 & 0.029 & -0.031 & 0.097 & \\
\hline$B G R$ & Middle & -0.109 & -0.152 & 3.066 & 2.805 & Type V \\
\hline $\mathrm{CHN}$ & Middle & -0.030 & -0.136 & 0.072 & -0.095 & \\
\hline FRA & High & -0.041 & -0.219 & 0.001 & -0.259 & \\
\hline TWN & High & -0.123 & -0.029 & 0.254 & 0.102 & \\
\hline CYP & High & -0.121 & 0.419 & 0.146 & 0.444 & Type VI \\
\hline ESP & High & -0.031 & 0.002 & 0.031 & 0.003 & \\
\hline PRT & High & -0.012 & 0.161 & 0.124 & 0.273 & \\
\hline AUT & High & 0.042 & -0.240 & 0.016 & -0.182 & Type VII \\
\hline DEU & High & 0.029 & -0.010 & 0.026 & 0.046 & \\
\hline TUR & Middle & 0.053 & -0.104 & 0.063 & 0.012 & \\
\hline DNK & High & 0.028 & 0.042 & 0.066 & 0.137 & Type VIII \\
\hline GRC & High & 0.067 & 0.267 & 0.054 & 0.387 & \\
\hline IDN & Low & 0.016 & 2.066 & 0.137 & 2.219 & \\
\hline $\mathrm{IRL}$ & High & 0.003 & 0.080 & 0.012 & 0.095 & \\
\hline MLT & High & 0.103 & 0.013 & 0.094 & 0.210 & \\
\hline
\end{tabular}

For example, in countries belonging to Type II, changes in import structure of final products contribute to global warming, and therefore mitigation countermeasures should be focused on shifting emissions-intensive technologies of final products produced overseas and/or trade patterns of final products. In countries belonging to Type IV or VIII, 
changes in import structure contribute to global warming; consequently, mitigation countermeasures adopted by these countries need to focus on trade patterns. On the other hand, in countries of Types V to VIII, industrial structure change contributes to global warming and therefore these countries need to take warming countermeasures that focus on reducing emissions from emissions-intensive industries. Thus, this study has shown the need for global warming countermeasures that consider the differences in the role of the structural changes in the eight country groups identified in this study.

\section{Conclusions}

This paper proposed a decomposition method to estimate how changes in domestic economic scale, industrial composition, domestic technology, import scale of intermediate products, import composition of intermediate products, import scale of final products, import composition of final products, and foreign technology affect the volumes of both territorial and extraterritorial $\mathrm{CO}_{2}$ emissions induced by imports during the 1995-2009 period. In addition, we similarly decomposed the changes in the export-based $\mathrm{CO}_{2}$ emissions into the changes in domestic technology, export scale of intermediate products, export composition of intermediate products, export scale of final products, and export composition of final products.

Based on the results obtained from the comprehensive decomposition analysis of territorial and extraterritorial $\mathrm{CO}_{2}$ emissions, the patterns of structural change in the 40 nations can be classified into eight types (Table 3). We found that structure changes and trade pattern changes have different roles according to the group type. Considering that economic growth increases global warming (IPCC 2014), the role that structural changes play in global warming is important for decision makers. There is thus an urgent need to draft comprehensive $\mathrm{CO}_{2}$ emissions reduction guidelines that consider the structural changes of each country. Specifically, international guidelines are needed that include, among other things, emissions reduction policies that set reduction targets from three sources $\left(\mathrm{CO}_{2}\right.$ emissions associated with intermediate product import composition, $\mathrm{CO}_{2}$ emissions associated with final product import composition, and $\mathrm{CO}_{2}$ emissions associated with domestic output composition) and that consider groups of countries in terms of those three sources, as in Table 3.

We also found that the export scale in the middle-income group of countries contributed as a major driver of territorial $\mathrm{CO}_{2}$ emissions associated with manufacturing during 1995-2008, whereas the export composition effect was negligibly small in both the highincome and middle-income group of countries during the same period and it has not played an important role in climate change.

\section{Additional file}

Additional file 1: Table S1. Results of decomposing territorial $\mathrm{CO}_{2}$ emission for exports (Unit: $\mathrm{Kt}_{2}$ ).

\section{Acknowledgements}

This research was supported by JSPS Grant-in-Aid for JSPS Fellows (No. 16J03790). I would like to thank two anonymous reviewers who provided very helpful comments.

Competing interests

The author declares that she has no competing interests. 


\section{Appendix}

See Tables 4 and 5.

\section{Table 4 Industry classification}

\begin{tabular}{|c|c|c|}
\hline Sector number & Description & Industry group \\
\hline 1 & Agriculture, hunting, forestry, and fishing & Primary industry \\
\hline 2 & Mining and quarrying & Secondary industry \\
\hline 3 & Food, beverages, and tobacco & \\
\hline 4 & Textiles and textile products & \\
\hline 5 & Leather, leather, and footwear & \\
\hline 6 & Wood and products of wood and cork & \\
\hline 7 & Pulp, paper, paper, printing, and publishing & \\
\hline 8 & Coke, refined petroleum, and nuclear fuel & \\
\hline 9 & Chemicals and chemical products & \\
\hline 10 & Rubber and plastics & \\
\hline 11 & Other nonmetallic mineral & \\
\hline 12 & Basic metals and fabricated metal & \\
\hline 13 & Machinery, nec & \\
\hline 14 & Electrical and optical equipment & \\
\hline 15 & Transport equipment & \\
\hline 16 & Manufacturing, nec; recycling & \\
\hline 17 & Electricity, gas, and water supply & \\
\hline 18 & Construction & \\
\hline 19 & $\begin{array}{l}\text { Sale, maintenance, and repair of motor vehicles and motorcycles; retail } \\
\text { sale of fuel }\end{array}$ & Tertiary industry \\
\hline 20 & $\begin{array}{l}\text { Wholesale trade and commission trade, except of motor vehicles and } \\
\text { motorcycles }\end{array}$ & \\
\hline 21 & $\begin{array}{l}\text { Retail trade, except of motor vehicles and motorcycles; repair of house- } \\
\text { hold goods }\end{array}$ & \\
\hline 22 & Hotels and restaurants & \\
\hline 23 & Inland transport & \\
\hline 24 & Water transport & \\
\hline 25 & Air transport & \\
\hline 26 & $\begin{array}{l}\text { Other supporting and auxiliary transport activities; activities of travel } \\
\text { agencies }\end{array}$ & \\
\hline 27 & Post and telecommunications & \\
\hline 28 & Financial intermediation & \\
\hline 29 & Real estate activities & \\
\hline 30 & Renting of M\&Eq and other business activities & \\
\hline 31 & Public admin and defense; compulsory social security & \\
\hline 32 & Education & \\
\hline 33 & Health and social work & \\
\hline 34 & Other community, social and personal services & \\
\hline 35 & Private households with employed persons & \\
\hline
\end{tabular}


Table 5 Income classification of countries examined in the study

\begin{tabular}{|c|c|c|c|}
\hline Country number & Country & Abbreviation & Income group \\
\hline 1 & Australia & AUS & High-income group \\
\hline 2 & Austria & AUT & \\
\hline 3 & Belgium & BEL & \\
\hline 4 & Canada & CAN & \\
\hline 5 & Cyprus & CYP & \\
\hline 6 & Czech Republic & CZE & \\
\hline 7 & Germany & DEU & \\
\hline 8 & Denmark & DNK & \\
\hline 9 & Spain & ESP & \\
\hline 10 & Estonia & EST & \\
\hline 11 & Finland & FIN & \\
\hline 12 & France & FRA & \\
\hline 13 & UK & GBR & \\
\hline 14 & Greece & GRC & \\
\hline 15 & Ireland & $\mathrm{IRL}$ & \\
\hline 16 & Italy & ITA & \\
\hline 17 & Japan & JPA & \\
\hline 18 & Korea & KOR & \\
\hline 19 & Lithuania & LTU & \\
\hline 20 & Luxembourg & LUX & \\
\hline 21 & Latvia & LVA & \\
\hline 22 & Malta & MLT & \\
\hline 23 & Netherlands & NLD & \\
\hline 24 & Poland & $\mathrm{POL}$ & \\
\hline 25 & Portugal & PRT & \\
\hline 26 & Russia & RUS & \\
\hline 27 & Slovakia & SVK & \\
\hline 28 & Slovenia & SVN & \\
\hline 29 & Sweden & SWE & \\
\hline 40 & Taiwan & TWN & \\
\hline 30 & USA & USA & \\
\hline 31 & Bulgaria & $B G R$ & Middle-income group \\
\hline 32 & Brazil & BRA & \\
\hline 33 & China & $\mathrm{CHN}$ & \\
\hline 34 & Hungary & HUN & \\
\hline 35 & Mexico & MEX & \\
\hline 36 & Romania & $\mathrm{ROM}$ & \\
\hline 37 & Turkey & TUR & \\
\hline 38 & Indonesia & IDN & Low-income group \\
\hline 39 & India & IND & \\
\hline 41 & Rest of world & RoW & \\
\hline
\end{tabular}


Received: 21 January 2016 Accepted: 19 July 2016

Published online: 02 August 2016

\section{References}

Ang BW (2004) Decomposition analysis for policymaking in energy: which is the preferred method? Energy Policy 32:1131-1139

Ang BW, Liu FL, Chew EP (2003) Perfect decomposition techniques in energy and environmental analysis. Energy Policy $31: 1561-1566$

Casler SD, Rose A (1998) Carbon dioxide emissions in the U.S. economy: a structural decomposition analysis. Environ Resour Econ 11:349-363

Davis SJ, Peters GP, Caldeira K (2011) The supply chain of CO emissions. Proc Natl Acad Sci USA 108:18554-18559

Dietzenbacher E, Los B (1997) Analyzing decomposition analysis. In: Simonovits A, Steenge AE (eds) Prices, growth and cycles. Macmillan, London, pp 108-131

Dietzenbacher E, Los B (1998) Structural decomposition technique: sense and sensitivity. Econ Syst Res 12:307-323

Dietzenbacher E, Hoen AR, Los B (2000) Labor productivity in Western Europe 1975-1985: an intercountry analysis. J Reg Sci 40:425-452

Dietzenbacher E, Los B, Stehrer R, Timmer M, de Vries G (2013) The construction of World Input-Output Tables in the WIOD project. Econ Syst Res 25:71-98

Hertwich EG, Peters GP (2009) Carbon footprint of nations: a global, trade-linked analysis. Environ Sci Technol 43:6414-6420

Hoekstra R, van den Bergh JJCJM (2003) Comparing structural and index decomposition analysis. Energy Econ 25:39-64 IPCC (2014) Climate change 2014: mitigation of climate change. https://www.ipcc.ch/report/ar5/wg3/

Kagawa S, Inamura H (2001) A structural decomposition of energy consumption based on a hybrid rectangular inputoutput framework: Japan's case. Econ Syst Res 13:339-363

Kagawa S, Yuriko G, Sangwon S, Keisuke N, Yuki K (2012) Accounting for changes in automobile gasoline consumption in Japan: 2000-2007. J Econ Struct 1(9):1-27

Leontief W, Ford D (1972) Air pollution and economic structure: empirical results of input-output computations. In: Brody A, Carter A (eds) Contributions to input-output analysis. North-Holland, Amsterdam, pp 9-30

Levinson A (2009) Technology, international trade, and pollution from US manufacturing. Am Econ Rev 99:2177-2192

Lin X, Polenske KR (1995) Input-output anatomy of China's energy use changes in the 1980s. Econ Syst Res 7:67-84

Nansai K, Kagawa S, Suh S, Inaba R, Moriguchi Y (2007) Simple indicator to identify the environmental soundness of growth of consumption and technology: "Eco-velocity of consumption". Environ Sci Technol 41:1465-1472

Nansai K, Kagawa S, Suh S, Fujii M, Inaba R, Hashimoto S (2009) Material and energy dependence of services and its implications for climate change. Environ Sci Technol 43:4241-4246

Okamoto S (2013) Impacts of growth of a service economy on $\mathrm{CO}_{2}$ emissions: Japan's case. J Econ Struct 2:1-21

Oshita Y (2012) Identifying critical supply chain paths that drive changes in $\mathrm{CO}_{2}$ emissions. Energy Econ 34:1041-1050

Park SH (1992) Decomposition of industrial energy consumption: an alternative method. Energy Econ 13:265-270

Peters G, Minx J, Weber CL, Edenhofer O (2011) Growth in emission transfers via international trade from 1990 to 2008. Proc Natl Acad Sci 108:8903-8908

Proops JLR (1984) Modelling the energy-output ratio. Energy Econ 6:47-51

Rose A, Casler SD (1996) Input-output structural decomposition analysis: a critical appraisal. Econ Syst Res 8:33-62

Rose A, Chen CY (1991) Sources of change in energy use in the U.S. economy, 1972-1982: a structural decomposition analysis. Resour Energy 13:1-21

Sun JW (1998) Changes in energy consumption and energy intensity: a complete decomposition model. Energy Econ 20:85-100

Tian X, Changb M, Shia F, Tanikawaa H (2014) How does industrial structure change impact carbon dioxide emissions? A comparative analysis focusing on nine provincial regions in China. Environ Sci Policy 37:243-254

Timmer MP, Dietzenbacher E, Los B, Stehrer R, de Vries GJ (2015) An illustrated user quide to the world input-output database: the case of global automotive production. Rev Int Econ 23:575-605

United Nations (1999) Handbook of input-output table compilation and analysis, studies in method series F, vol 74. U. N, New York

Voigt S, De Cian E, Schymura M, Verdolini E (2013) Energy intensity developments in 40 major economies: structural change or technology improvement? Energy Econ 41:47-62

Wier M (1998) Sources of changes in emissions from energy: a structural decomposition analysis. Econ Syst Res 10:99-112

Wood R, Lenzen M (2009) Structural path decomposition. Energy Econ 31:335-341

World Bank (2013). http://siteresources.worldbank.org/DATASTATISTICS/Resources/CLASS.XLS. Accessed 26 July 2016

Xu Y, Dietzenbacher E (2014) A structural decomposition analysis of the emissions embodied in trade. Ecol Econ 101:10-20 